\title{
ANALYSIS OF ENTREPRENEURSHIP IN ROMANIA COMPARATIVE WITH THE EU COUNTRIES - 27
}

\author{
Tudor Pendiuc \\ Constantin Brancoveanu University, Pitesti, Romania \\ Pitesti Municipality, Romania \\ E-mail: tpdoru@gmail.com, cabinetprimar@primariapitesti.ro
}

Elena Carmen Lis

Pitesti Municipality, Pitesti, Romania

E-mail: ecarmen.27@gmail.com

\begin{abstract}
Entrepreneurship is a socio-economic phenomenon of great complexity, defining the market economy system. As the business environment becomes more complex and competitive, the entrepreneurs must become more creative and receptive to what is new and innovative.

For Romania the promotion and development of entrepreneurship were a central objective in the last decade for job creation, competitiveness growth and sustainable economic development. Regardless of the method chosen to develop a business, the entrepreneur must operate with criteria of rationality in terms of choices, decisions and performance evaluation.

This work aims a comparative analysis of the main issues concerning the development of entrepreneurship in Romania compared to other EU countries. It emphasizes the following aspects: a) option on the status of employee/contractor; b) the important factors in the decision on starting/taking over a business; c) difficulties to start/taking over a business. Based on the analysis were resulted conclusions on the main economic and social features of entrepreneurship in Romania compared to other European Union member states. It was stressed the importance of entrepreneurship development on the Romanian economy, by analyzing the factors that encourage or discourage the entrepreneurship.

The research was conducted using a variety of bibliographic sources such as statistics, analysis, reports, professional articles.
\end{abstract}

Key words: entrepreneurship, entrepreneur, business, Romania, E.U. member states.

\section{Introduction}

Political, economic and social changes that have marked in the last decade the EU states and in this context, also Romania, have had a major impact on the business environment and how it is perceived the entrepreneurship.

Building a competitive European economy requires to create new jobs, development of new products and services, which involves the exploitation of the creative potential and to encourage the entrepreneurship in each member country.

The entrepreneurship entails to identify the economic opportunities and to use them by starting a new business or taking over and developing the existing business.

Many researchers have made an important contribution to the development of the concept of entrepreneurship. According to their studies, business cycles are seen as the result of innovation, which consists of the generation of a new idea and its implementation in a new pro- 
Tudor PENDIUC, Elena Carmen LIS. Analysis of Entrepreneurship in Romania Comparative with the EU Countries - 27

PROBLEMS

OF MANAGEMENT

IN THE $21^{\text {st }}$ CENTURY Volume 8, 2013

82

duct, process or service, leading to the dynamic growth of the national economy, the increase of employment, and the creation of pure profit for the innovative enterprise (Schumpeter, 1911; Schumpeter, 1942; Dejardin, 2000; Jääskeläinen, 2000; Thurik \& Wennekers, 200; Barreto, 1989). Entrepreneurship is more than just a mechanical economic factor (Pirich, 2001, pp. 1415). The entrepreneurship stimulates the innovation and the change. According to Schumpeter (1911), "everyone is an entrepreneur when he actually carries out new combinations". People are looking to find optimal solutions to adapt the specifics of the current socio-economic environment and the challenges which appeared in the labor market by developing the skills and abilities that they have. The success in entrepreneurship involves a lot of will, tenacity, ambition, responsibility, knowledge, entrepreneurial skills. Among the essential qualities of an entrepreneur, include the priority: education, initiative, visionary, flexibility, ability to communicate effectively, adaptability to change, dedication, self-discipline. Along with all of this, we should mention the availability to give up, often, to a convenient lifestyle and the courage to face challenges, to take risks.

The development of the business amplifies the action and the consequences of all types of risks from the perspective of the diversity of forms under which they appear (Dragomir, 2012, p. 162). According to Knight F.H. (1967) and Drucker P. (1970) the entrepreneurship is defined as the activity of people willing to risk their careers, activity and funds available to put in practice a new idea. Some researchers suggest that risk taking is typical for entrepreneurs and less important for employees. (Brown et al., 2011). The risks requires the courage. The courage means responsibility for the accomplished actions. An entrepreneur always assumes risk in his work, but these risks are calculated. Entrepreneurs can learn from both their own and others' successes and failures, which enables them to improve their skills and adapt their attitudes (Caree \& Thurik, 2002).

The functional roles of entrepreneurs include coordination, innovation, neutralization uncertainty, supply of capital, decision making, property and resource allocation (Friijsetal, 2002; Jääskeläinen, 2000). Summarizing these roles, Wennekers and Thurik (1999, pp.46-47) define the entrepreneurship as ,... the ability and willingness of individuals, on their own or in teams within and outside of existing organizations, to perceive and create a new economic opportunities (new products, new production methods, new schemes of organization and new product-market combinations) and introduce their ideas in the market, despite uncertainty and to other obstacles, by making decisions about location, form and use of resources and institutions."

Regardless of the field, encourage to start or take over a business and the entrepreneurial skills development, should be important targets for each European country, taking into consideration the benefits that the entrepreneurship brings into economically and socially.

\section{Field of Research}

The entrepreneurship is the engine of economic and social development of a country, helping to create new jobs and increase the competitiveness. The increasing importance of entrepreneurship for economic development of a country is expressed by Michael Porter: "Invention and entrepreneurship are at the heart of national advantage" (Porter, 1990, p. 125). The European Union encourages the development of entrepreneurship, promoting the creative and entrepreneurial behavior in all Member States. The decision to start/take over a business is influenced by many factors, including: economic and social situation as a whole, the legislative and bureaucratic difficulties, the existence of a suitable market opportunities, financial obstacles; need to acquire new skills to manage a business. U.E. has a duty to reduce the barriers and obstacles who block the entrepreneurship of his citizens, encouraging the creative and entrepreneurial behavior in all Member States. In this context, this research highlights the role 
that entrepreneurship occupies in the European market by highlighting the dynamic factors and the motivations who influence favorable or unfavorable the entrepreneurial behavior in EU countries and in particular, in Romania.

\section{The Research Purpose}

The aim of this study was to analyze the main economic and social features of entrepreneurship in Romania, in the comparative context of EU countries. Are outlined the issues who must to be strengthened, to create the premises underlying the development of entrepreneurial performance in Romania.

\section{Methodology of Research}

\section{Information Sources for Research}

Meant to guide the scientific approach, the methodology of research includes a set of principles, rules, methods, techniques and tools of investigation (Stefanescu C., 2009, p 26). The complexity of research, regarding the entrepreneurship in Romania, in the context of comparative EU countries, involved the use of appropriate tools and techniques of investigation. The information sources for research consisted in processing and interpretation of survey results conducted by TNS Opinion \& Social Network at the request of the European Commission in June-August 2012. The methodology used is that of Eurobarometer polls. The poll aims to capture and measure the views of a representative group of people on the state of entrepreneurship in the European Union in the period of June-August 2012. Were targeted more several aspects. Of these, our analysis focuses on the following elements: the status of the employee / entrepreneur; important factors in the decision on starting/taking over a business, difficulties to start/take over a business.

\section{Sample Research}

The study included more than 42,000 respondents in 27 Member States of the European Union. For selecting the representative samples, was used quota sampling. Was established a quota control. The people interviewed were from different social and demographic groups, thus ensuring the required level of representativeness of the sample. The poll was conducted on the interview based. The questions were addressed and formulated by phone, as not to induce subjective responses.

\section{Results of Research}

\section{Analysis with Reference to European Respondents, Option Employee / Contractor}

A person's decision to opt for the status of entrepreneur is not easy and depends on numerous factors. According to data published in Eurobarometer report 354/2012, ask what they would prefer to choose if they had the chance, among the status of employed or entrepreneur, a proportion of $37 \%$ of the total number of respondents from EU Member States, said that they would prefer to be self-employed, while $58 \%$ opted for employees. These medium proportions vary from country to country and over time have tended to rise or fall. Compared to the report published in December 2009, Flash Eurobarometer 283, the percentage of those seeking freelance work is declining (in $201237 \%$ of all EU citizens have opted for the status of entrepreneurs compared to $45 \%$ in 2009). The willingness to work on their own, has the fewest adherents 
Tudor PENDIUC, Elena Carmen LIS. Analysis of Entrepreneurship in Romania Comparative with the EU Countries - 27

PROBLEMS

OF MANAGEMENT

IN THE $21^{\text {st }}$ CENTURY

Volume 8,2013

in Sweden (22\%), Finland (24\%), Denmark (28\%) and Slovenia (28\%). The majority preference of U.E. citizens for employment status is determined by job security, stable income, fixed time working, protection through security and social insurance. Also, the current economic situation, the effects of economic and financial crisis, fear of bankruptcy and job insecurity, have reduced the percentage of those who would like to engage in entrepreneurial activities. Only in six countries the option for their own business has a majority share (Table 1). Lithuania (58\%) and Greece (50\%) are the countries where this option is reflected by the highest percentage.

Regarding Romania, the percentage of those who would like to start a business of their own (self-employed) is higher than the percentage of those who prefer employee status, despite the economic and financial crisis, which does not encourage the entrepreneurship initiatives. Thus, $48 \%$ of romanian respondents were in favor of entrepreneur status, while $47 \%$ opted for the status of employee.

Socio-Demographic data registered to E.U level shows that: men, young people and people with higher levels of education, were in favor of entrepreneurship and self-employment. $45 \%$ of young people with age between 15-24 say they would prefer self-employed. Their option is explained by the desire to have the freedom to choose the place and time of work and the chance to use their skills in personal interest. 
Table 1. Share Option (\%) in choosing the status of employee or contractor.

\begin{tabular}{|c|c|c|c|c|}
\hline Country & Employee & Entrepreneur & No preference & Don't know \\
\hline Sweden & 74 & 22 & 2 & 2 \\
\hline Finland & 73 & 24 & 1 & 2 \\
\hline Denmark & 66 & 28 & 1 & 5 \\
\hline Slovenia & 66 & 28 & 4 & 2 \\
\hline Belgium & 65 & 30 & 3 & 2 \\
\hline Germany & 65 & 29 & 3 & 3 \\
\hline Netherlands & 64 & 31 & 3 & 2 \\
\hline Austria & 63 & 34 & 1 & 2 \\
\hline United Kingdom & 63 & 33 & 2 & 2 \\
\hline Spain & 62 & 35 & 1 & 2 \\
\hline Luxembourg & 61 & 36 & 1 & 2 \\
\hline Slovakia & 61 & 33 & 2 & 4 \\
\hline Malta & 61 & 34 & 2 & 3 \\
\hline Ireland & 61 & 37 & 1 & 1 \\
\hline Czech & 64 & 34 & 2 & 3 \\
\hline France & 57 & 40 & 2 & 1 \\
\hline Hungary & 55 & 39 & 4 & 2 \\
\hline Estonia & 54 & 35 & 5 & 6 \\
\hline Poland & 50 & 47 & 2 & 1 \\
\hline Italy & 48 & 44 & 3 & 4 \\
\hline Portugal & 47 & 49 & 1 & 3 \\
\hline Romania & 47 & 48 & 3 & 2 \\
\hline Cyprus & 46 & 45 & 5 & 4 \\
\hline Latvia & 45 & 49 & 3 & 3 \\
\hline Greece & 43 & 50 & 5 & 2 \\
\hline Bulgaria & 40 & 49 & 5 & 6 \\
\hline Lithuania & 32 & 58 & 3 & 7 \\
\hline
\end{tabular}

Source: Analytical Report, Flash Eurobarometer no.354/2012

The recorded data provide an interesting information about the entrepreneurial behaviour of the respondents interviewed where financial resources should not be a problem. When were asked what they would do with an inherited amount, having the option to start a business, buying a home, saving amount, the purchase of luxury goods, reduction/cessation of activity, $33 \%$ of European respondents would buy a house or would repay the mortgage it holds . The lowest figures for use the money to start a business, were registered in Finland (6\%), Sweden (6\%), Denmark (7\%), Germany (7\%), Austria (9\%), Belgium (9\%). English, French, Italians, in proportion of $39 \%-40 \%$ prefer to buy a house, while the Slovenes, Cypriots and Swedes 
Tudor PENDIUC, Elena Carmen LIS. Analysis of Entrepreneurship in Romania Comparative with the EU Countries - 27

PROBLEMS

OF MANAGEMENT

IN THE $21^{\text {st }}$ CENTURY Volume 8,2013

choose that option to save money (in proportion of 36\% and 39\%). According to sociological data, men are more likely than women to use the money to start a business $(20 \%$ vs. $14 \%)$, while women choose a higher proportion than men for buying a home (36\% vs. $31 \%$ ). Regarding the elderly, are in favor to save money (21\%) and less willing to invest money in starting a business $(10 \%)$. With a strong entrepreneurial spirit, young respondents in proportion of $23 \%$ are open to use the amount to start a business.

For respondents of Romania starting a business is the option with the highest percentage (54\%). Use the money for buying a house is less popular, accounting for $20 \%$ of respondents, while $15 \%$ choose to save money. A much lower percentage of respondents represented opting for buying luxury products (6\%) or reduction /cessation of activity (Figure 1).

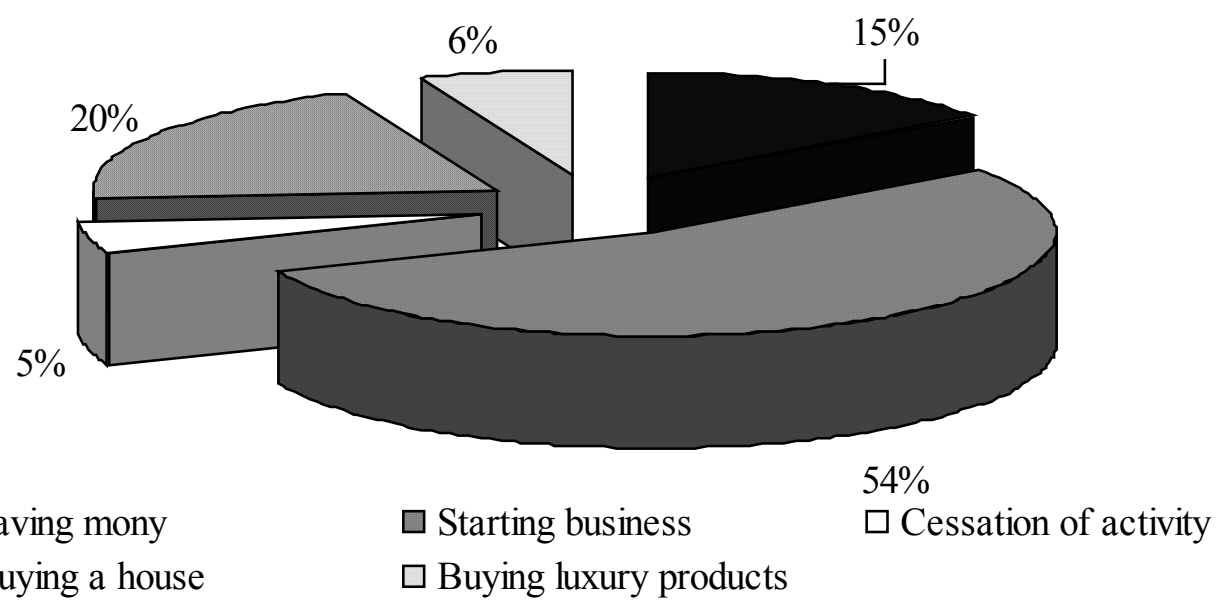

Source: Analitical Report, Flash Eurobarometer no.354/2012

Figure 1: Romanians option of spending an amount of inherited money.

Most of Romanians see the entrepreneurship as one of the solutions that can provide economic and social independence. The majority option is for the entrepreneur status of respondents from Romania, is due to several reasons, among the most important relate to the desire of self-realization, financial independence and decision-making, the desire for self-fulfilment, the desire to exploit the opportunities that arise. Moreover, the status of the entrepreneur and the top manager enjoys a very good reputation in Romania compared to other European countries.

\section{Analysis about the Important Factors in the Decision to Start/Take over a Business}

The decision to start or take over a business is a complex process and involves many aspects that must be taken into account. Of these the most important relate to: a) identify the best business ideas through the complex analysis of the market and identify the consumer needs which were not satisfied, b) the funds needed to start/take over the business, c) contact with a suitable business partner d) the role of a model e) dissatisfaction with previous work, f) resolution of environmental and social needs unmet; g) correctly predict for chances of success and the risks involved in a business. Along with these elements, as important as this, starting a business requires a great investment of professionalism creativity, tenacity and not the least, a strong desire to succeed. For the European respondents interviewed an appropriate idea and financial means, are the most important factors in the decision to start or take over a business (Figure 2). Thus, for $87 \%$ of respondents the appropriate business idea is important, while 
only for $12 \%$ this element is not important. Higher rates recorded in Hungary $(94 \%)$, Spain

$(93 \%)$ and Greece ( $92 \%)$.

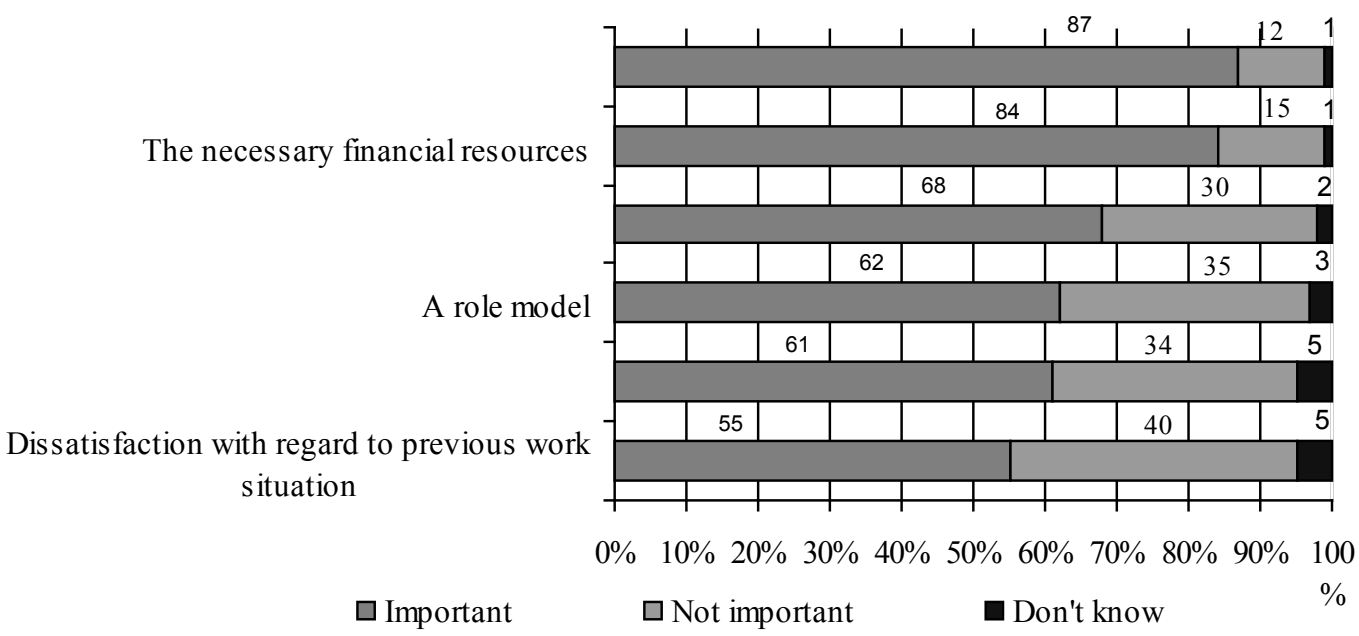

Source: Analitical Report, Flash Eurobarometer no.354/2012

\section{Figure 2: Important factors in the decision on starting / taking over a business marked by EU respondents (\%)}

Financial resources for starting a business are considered important in the decision to start/take over a business for $84 \%$ of respondents. In third place among the elements considered important for starting a business, is the contact with a suitable business partner ( $68 \%$ of respondents). The percentages recorded for this item are higher in Hungary $(90 \%)$, Latvia (88\%) and Lithuania (85\%).

The model role is considered important in the decision to start a business by $62 \%$ of respondents, while more than a third of respondents (35\%) say that the model role is important. For $61 \%$ of respondents to solve a social and environmental needs is an important factor, while $34 \%$ say that this is not an important factor in their decision. Statistics show that for women to resolve an unmet social and an environmental needs is an important element in the decision on starting/taking over a business, in a greater proportion than for men ( $65 \%$ versus $58 \%$ ).

Dissatisfaction for the previously workplace is an important factor for decision to start/ take over a business for $55 \%$ of respondents from EU countries, while for $40 \%$ of them this element was not considered important. Dissatisfaction at the workplace was less relevant to respondents from: Norway (35\%), Denmark (32\%), Sweden (35\%). We want to emphasize that in communist countries of Central and Eastern Europe, where the economic situation is still precarious, the percentage for dissatisfaction about the previous workplace, is an important decision for starting/taking over a business more than 50\%: Estonia (60\%), Hungary (58\%), Czech Republic (54\%), Poland (54\%), Slovakia (51\%), Latvia (51\%).

The way which Romanian respondents have staged, the degree of importance, the factors underlying the decision to start/ take over a business, is presented in Figure 3. The financial resources and an adequate idea for a business occupy for Romanian respondents the first two places in the hierarchy. $93 \%$ of respondents consider the financial resources the most important factor in starting a business. $88 \%$ of Romanian respondents grant an importance to the existence of an adequate business ideas. 

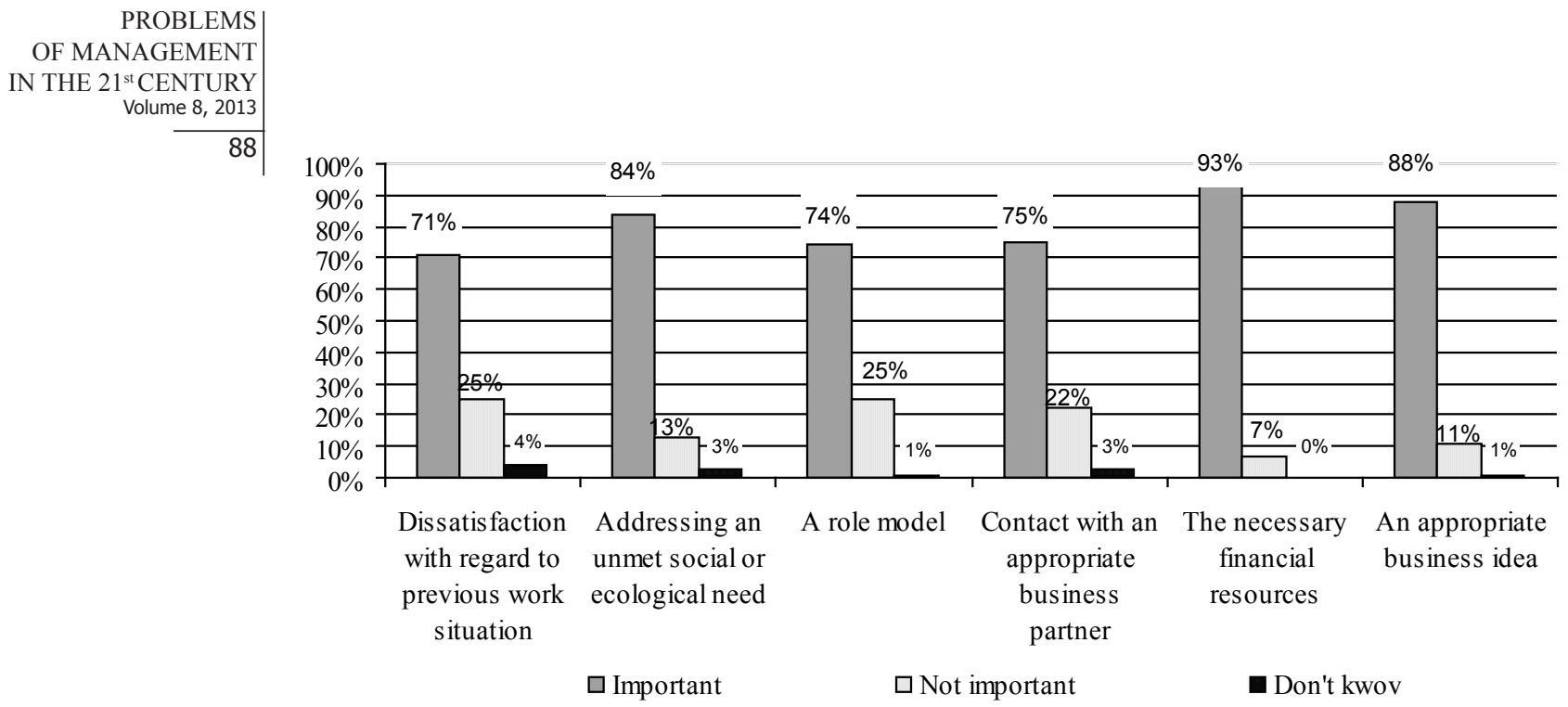

Source: Analytical Report, Flash Eurobarometer no. 354/2012 Figure 3: The important factors in the decision on starting / taking over a busi-
ness for respondents of Romania (\%)

Regarding the contact with a suitable business partner, for $77 \%$ of Romanian respondents this is an important factor for starting/taking over a business. $22 \%$ of respondents did not attach importance for the business partner, while 3\% did not reply. The role of a successful model counts as important in the decision to start a business from $74 \%$ of Romanian respondents. The high percentage obtained, confirms the preferences of Romanians for models/successful legends.

A pleasant surprise for the entrepreneurship from Romania is the result of an investigation relating to the settlement of social and environmental unmet needs as an important factor in the decision to start/take over a business. $84 \%$ of Romanian entrepreneurs interviewed have the opinion that the resolution of unmet social and environmental needs is an important factor in their decision to start a business. The percentage is impressive, being the highest, who was registered in EU States. It is a proof of major interest for the quality of life by solving the social problems and those related to environmental protection. The principles of social and environmental development, enhances the credibility of the business, establish a suitable framework and increase the advantage towards the competitors. Moreover, in Romania exist contractors who have decided to be actively involved by integration of environmental policies into their business activities and develop strategies to transform the company into a responsible business from the point of economic and social view. A company who has the wish to operate on the long term and to remain competitive in an increasingly globalized economy, must to be responsible the point of environmentally and socially view and to develop policies and strategies for social and enviroment protection (Dragomir, Pânzaru, 2013, p 341). Romania holds the leading place in terms of the respondent percentage who consider dissatisfaction about the previous employment, as an important factor in the decision to start a business (71\%). 
The decision to start/retrieve a business is often difficult and can be blocked by many difficulties. According with the investigation achieved, the barriers and difficulties the most frequently invoked that confront entrepreneurs in starting/taking over a business, relate to: lack of financial resources, administrative complexity, difficulties in obtaining the necessary information, the risk of failure (Figure 4).

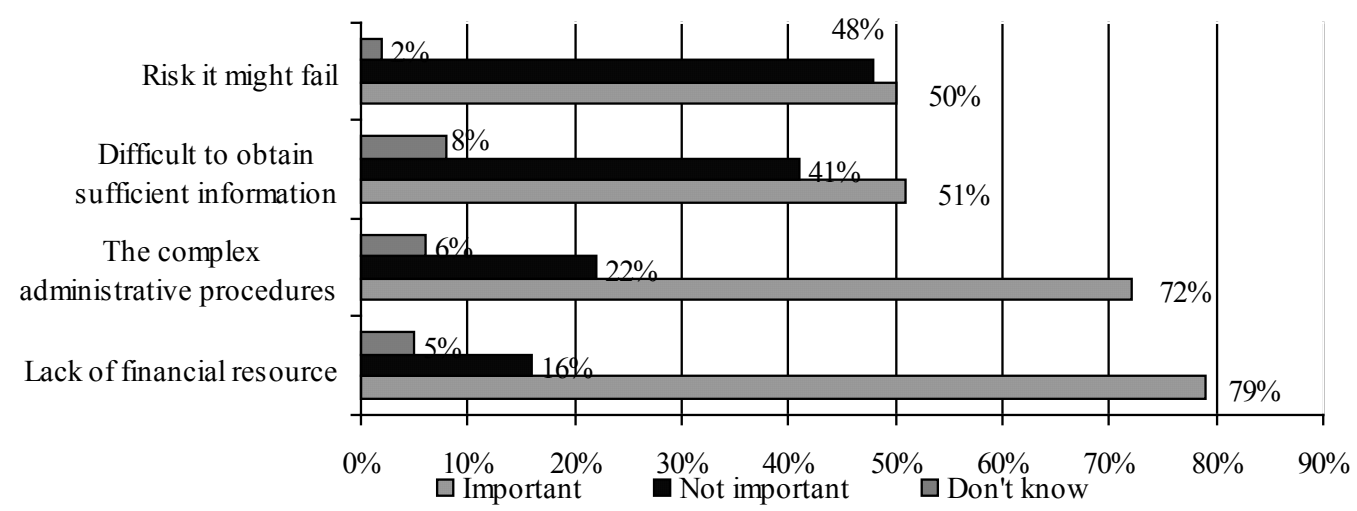

\section{Figure 4: Difficulties which marks the decision to start / take over of a business, in vision of European respondents (\%)}

The lack of financial resources is a major barrier in the decision to start a business. This is confirmed by the large number of respondents from EU countries (79\%) for which the insufficient financial resources limit the decision to start/take over a business. Exist national big differences on these questions. The lack of capital is a barrier for an entrepreneurship at least nine out of ten people from Greece (96\%), Cyprus (92\%), Ireland (90\%), Portugal (90\%).

The complexity of administrative process, the existence of a difficult bureaucratic procedures represent a barrier in the decision to launch/retrieve a business for $(72 \%)$ of European respondents. In five states of U.E. the percentage who agree that it is difficult to start a business because of the complexity of the administrative process exceeds $80 \%$. These are: Greece $(85 \%)$, Italy (85\%), Romania (85\%), Lithuania (81\%) and Bulgaria (80\%).

Insufficient information about the way to start a business constitutes a barrier in the decision to start a business for $51 \%$ of European respondents. Respondents' assessments differ greatly from one country to another. Thus, while most of the respondents from Greece (77\%), Portugal (70\%), Bulgaria (68\%), consider the lack of information an obstacle in the decision to start a business and only $20 \%$ of respondents from the Netherlands are complaining this aspect.

The risk of failure and its consequences for a professional and personal lives are regarded as a serious obstacle in the decision to start a business by $50 \%$ of respondents from EU countries. The opinions on starting a business, where there represents a risk of failure varies from country to country. The countries with the highest percentage of respondents who do not want to start a business, if there exist a risk of failure are: Portugal (66\%), Lithuania (65\%), Malta (65\%), Hungary (62\%), Italy $(60 \%)$. The concerns about the risk of failure is much lower for the respondents from Northern European countries, countries with a stable economic development: Ireland (30\%), Denmark (35\%), Finland (39\%). 
PROBLEMS

OF MANAGEMENT

IN THE $21^{\text {st }}$ CENTURY Volume 8, 2013

Asked to mention the risks that scare the most, respondents noted, in the first place, the risk of bankruptcy- $43 \%$, followed by the risk of losing the property- $37 \%$, the risk of fluctuating income gain, irregular-33\%, insecurity workplace-19\%, the risk of suffering a personal failure$15 \%$, the need to devote too much energy or time for business in the damage of personal life $-13 \%$ ((Figure 5).

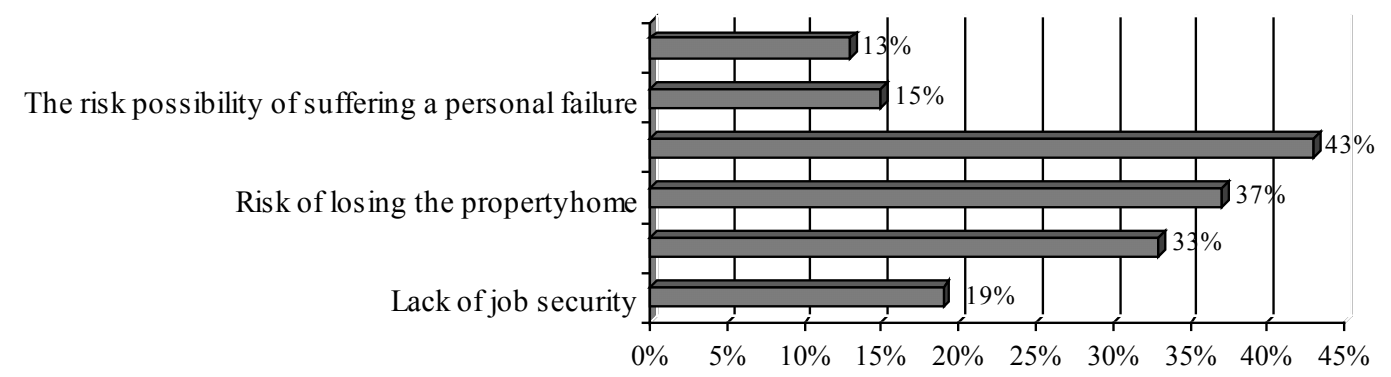

\section{Figure 5: The worst fears of European respondents on the decision to start / take over a business (\%).}

The share of respondents who cited the risk of bankruptcy as a barrier to starting a business, is more than a half in Greece (52\%), Portugal (51\%), Luxembourg (50\%) and Spain $(50 \%)$. On other opposition pole, fear of failure is lower in Finland (23\%) and Bulgaria (30\%). The risk of loss the property is estimated in a high proportion as an obstacle to starting a business by the respondents from Spain (55\%), UK (47\%), Ireland (45\%) and Hungary (45\%). At least $40 \%$ of respondents from EU countries said that they would not start a business because of the irregular income. This fear was expressed in a big percentage of the respondents from Sweden (44\%), Latvia (43\%), Finland (41\%) and Poland (41\%). Less concerned about the lack of a fixed income are the respondents from Lithuania (22\%), Bulgaria (24\%), Italy (27\%).

The insecurity of the workplace is a concern that prevents the start / take over a business for a higher percentage of respondents from Belgium (29\%), Italy (27\%), Slovakia (26\%). The fear of risk to suffering a personal failure if they start a business is higher for respondents from Cyprus (26\%), Switzerland (23\%), France (19\%). Not the same thing happens with the respondents from Norway $(8 \%)$, Italy $(9 \%)$ and Denmark $(10 \%)$, where the risk of suffering a personal failure is not a factor to worry a large number of respondents.

The need to devote too much energy or time for business, is particularly worrying for respondents from Sweden (34\%), Finland (33\%) and Malta (26\%). Instead, Bulgarians, Lithuanians, Croatians have mentioned this thing in a smaller proportion: Croatia $(9 \%)$, Bulgaria $(8 \%)$ and Lithuania.

According to the socio-demographic registered data at the level of EU countries, women consider the risk of failure an important barrier in the decision to start a business in a greater proportion than men $(53 \%$ versus $46 \%)$. Older respondents have, also a reluctant attitude towards the risk of failure compared with young people between $15-39$ years (56\% versus 43 $44 \%)$.

Regarding the respondents of Romania, invited to mark the obstacles that stand in the way of the decision to start or take over a business, they have shown up to $90 \%$ the lack of financial resources. The administrative complexity and the difficult bureaucratic procedures were reported by $85 \%$ of the respondents, while $73 \%$ of respondents reported the insufficient information on all the activities involved in starting/taking over a business represent a serious barrier to the decision to start a business (Figure 6). The risk of failure is perceived as a barrier to decision-taking or starting a business by $66 \%$ of respondents. 


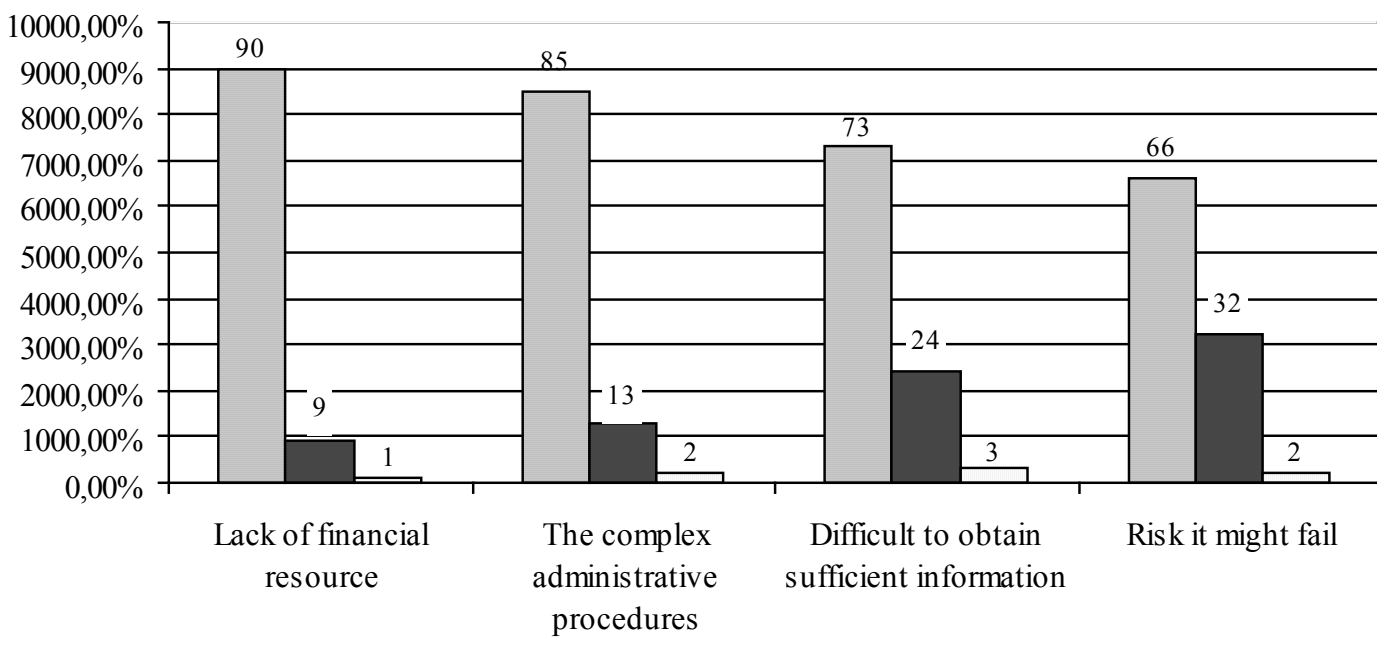

\section{Figure 6: Share of obstacles (\%) of the decision to start / take over of a busi- ness in vision of Romanian respondents.}

Regarding the fears of Romanian respondents about starting/taking over a business, 56 $\%$ of them invokes the risk of bankruptcy. This percentage places Romania among the European countries with the most respondents whose attitude is aversion (fear ) to the risk of bankruptcy and would not start a business because of this. The fear of losing property is for $25 \%$ of Romanian respondents a factor preventing them from starting a business and the risk of fluctuating income scares get $26 \%$ of respondents. Job insecurity is an obstacle in the decision to become entrepreneurs for $15 \%$ of Romanian respondents . The risk of suffering a personal failure (18\%) and the need to devote too much time or energy for business in the detriment of his personal life $(10 \%)$ are also reasons of fear for Romanian respondents, reasons which prevent the decision to launch/retrieve a business.

\section{Conclusions}

In the current economic and social context, the entrepreneurship development is a premise for economic and social development of a country. Entrepreneurship contributes to the creation of workplaces, increase the productivity and competitiveness, social achievements and improving the quality of life. Given the conditions of economic and financial crisis, the lack of financial resources, the risk of failure, the fear of failure, the insecurity at workplace represent strong brakes for many people who would like to start a business. More than ever, the European Union has a duty to encourage the entrepreneurship in member countries and the initiatives to create new jobs, new products and services. Promoting the entrepreneurship is a central objective of the European Union. Recently, the European Commission has included the promotion of entrepreneurship in EU countries, in 2020 Strategy, which recognizes the entrepreneurship and self- employment as one of the key elements of smart and sustainable European economy.

Regarding Romania, the data presented in this study show the interest of Romanians in the development of entrepreneurship. Romanian respondents opted if they may choose, in a large proportion (48\%) in favor of contractor status. Moreover, according to several national studies, the population of Romania encourages the specific values of entrepreneurship: honesty, 
Tudor PENDIUC, Elena Carmen LIS. Analysis of Entrepreneurship in Romania Comparative with the EU Countries - 27

PROBLEMS

OF MANAGEMENT

IN THE $21^{\text {st }}$ CENTURY Volume 8, 2013

tenacity, seriousness, courage, respect for social norms, decent behavior (Abrudan, Nastase, 2012, p. 139). Regarding the obstacles that hinder the entrepreneurial activity, these are also in the vision of Romanian respondents, similar to those marked by European respondents: lack of financial resources, the administrative complexity, difficulties in getting the necessary information to commence a business, the risk of failure. Survey data reveal a large percentage of Romanian respondents who has fear to start a business because of the risk of failure and its consequences for professional and personal life. These concerns are explained by the fact that in our national system of values, we meet features who do not resonate with the model of entrepreneurship: avoiding the conflict and risk, short-term thinking, the greater desire of safety and stability that offers to you the status of employee, insufficient efforts to develop the entrepreneurial skills.

Nevertheless, the study that I have made proves that in Romania the entrepreneurship can be successfully developed. The manifestation of a proactive and open attitude towards the entrepreneurial system, creating a favourable environment for the development of entrepreneurial skills, reducing the administrative burdens and simplifying the bureaucratic procedures, reducing the tax obstacles, promoting a culture entrepreneurial positive to taking risks, in our opinion, solutions that can be applied in Romania. For all of these require a commitment, an active involvement, responsibility and tenacity.

\section{References}

Abrudan, D., \& Năstase, M. (2012). Realities and challenges concerning Entrepreneurship education in Romania. Review of General Management, 16 (2), 136-148.

Barreto, H. (1989). The Entrepreneur in Microeconomic Theory: Disappearance and Explanation. London: Routledge.

Brown, S., Dietrich, M., Ortiz-Nunez, A., \& Taylor, K. (2011). Self-employment and attitudes towards risk: timing and unobserved heterogeneity. Journal of Economics, Psychology, 32, 425-433.

Carree, M., \& Thurik, A. R. (2002). The Impact of Entrepreneurship on Economic Growth. In Acs, Z., \& Audretsch, D. B. (2003). International Handbook of Entrepreneurship Research. Boston/Dordrecht: Kluwer Academic Publishers.

Dejardin, M. (2000). Entrepreneurship and Economic Growth: An Obvious Conjunction? Namur, Belgium: University of Namur Publishers.

Drucker, P. (1970). Entrepreneurship in Business Enterprise. Journal of Business Policy, 1, 59-86.

Dragomir, C., \& Pânzaru, S. (2013). Eco-development - the priority of sustainable economic development. Eco-Economy and Sustainable Development, 2, 335-345.

Dragomir, C. (2012). Causes generating risks in the business management. Review of General Management, 16 (2), 160-167.

Knight, K. (1967). A descriptive model of the intra-firm innovation process. Journal of Business of the University of Chicago, 40, 158-169.

Friijsetal, C., Paulsson, T., \& Karlsson C. (2002). Entrepreneurship and Economic Growth: A Critical Review of Empirical and Theoretical Research. Östersund, Sweden: Institutet för tillväxtpolitiska studier.

Flash Eurobarometer 354, Entrepreneurship in the EU and Beyond, 2012 June-August, Retrieved June 22, 2013, from http://ec.europa.eu/public_opinion/flash/fl_354_en.pdf .

Jääskeläinen, M. (2000). Entrepreneurship and Economic Growth. Helsinki: Institute of Strategy and International Business.

Pirich, A. (2001). An interface between entrepreneurship and innovation: New Zealand SMEs perspective. Paper prepared for the 2001 DRUID Conference, Aalborg, Denmark.

Porter, M. E. (1990). The Competitive Advantage of Nations. New York: Free Press.

Schumpeter, J. A. (1911). The Theory of Economic Development: An Inquiry into Profits, Capital, Credit, Interest and the Business Cycle. 1934 translation. Cambridge, MA: Harvard University Press.

Schumpeter, J.A. (1942). Capitalism, Socialism, and Democracy. (3rd Ed.). New York: Harper and Bros. 
Tudor PENDIUC, Elena Carmen LIS. Analysis of Entrepreneurship in Romania Comparative with the EU Countries - 27

PROBLEMS

OF MANAGEMENT

IN THE $21^{\text {st }}$ CENTURY

Ştefănescu, C. (2008). Management of business. Bucharest: Romania of Tomorrow Publishing House.

Ştefănescu, C. (2009). Scientific Research Methodology in Management. Bucharest: Romania of TomorVolume 8, 2013 row Publishing House.

Thurik, R., \& Wennekers, S. (2001). A Note on Entrepreneurship, Small Business and Economic Growth. Rotterdam: Erasmus Research Institute of Management Report Series.

Wennekers, S., \& Thurik, R. (1999). Linking entrepreneurship and economic growth. Small Business Economics, 13 (4), 46-47.

Advised by Constantin Bratianu, Academy of Economic Studies, Bucharest, Romania

Received: September 26, 2013

Accepted: November 18, 2013

Tudor Pendiuc

PhD., Professor, Constantin Brancoveanu University, Pitesti, Romania.

Mayor of Pitesti Municipality, Victoriei Street, 24, Arges County, Pitesti, Romania.

E-mail: tpdoru@gmail.com, cabinetprimar@primariapitesti.ro

Elena Carmen Lis

PhD., Head Office, Office for the Promotion of Pitesti Municipality, Pitesti, Romania.

E-mail: ecarmen.27@gmail.com, cabinetprimar@primariapitesti.ro 